\section{Impact of diabetes mellitus and obesity on delivery outcomes}

\author{
Jovana Radakovic ${ }^{1}$, Snezana Rakic ${ }^{1,2}$, Lazar Nejkovic ${ }^{1}$, \\ Minja Stankovic ${ }^{1}$, Jovana Gasic ${ }^{1}$ \\ ${ }^{1}$ University Clinic for Gynecology and Obstetrics "Narodni front", \\ Belgrade, Serbia \\ ${ }^{2}$ University of Belgrade, Faculty of Medicine
}

\section{Apstrakt}

Diabetes mellitus (DM) and maternal obesity are in parallel related with adverse maternal and neonatal outcomes. Examination of the combined association of these common metabolic problems with pregnancy outcomes is an important question. Objective of our study was to determine associations of diabetes mellitus and obesity with adverse delivery outcomes. The primary outcome measures were duration of labor, mode of delivery, Apgar scores in $1^{\text {st }}$ and $5^{\text {th }}$ minute, obstetric interventions and maternal injuries at births. Women with DM were more likely to have Cesarean Section $(p<0.01)$ and less likely to have had an episiotomy and perineal repair than women without DM (all $\mathrm{p}<0.05$ ). Connections between DM and obesity with other adverse outcomes of labor have not been found.

Ključne reči: diabetes mellitus, obesity, delivery outcomes

\section{Uticaj dijabetesa i gojaznosti na ishod porođaja}

\author{
Jovana Radaković ${ }^{1}$, Snežana Rakić ${ }^{1,2}$, Lazar Nejković ${ }^{1}$, \\ Minja Stanković1 ${ }^{\text {, Jovana Gašić }}{ }^{1}$ \\ ${ }^{1}$ Univerzitetska Klinika za ginekologiju i akušerstvo „Narodni front“, \\ Beograd, Srbija \\ ${ }^{2}$ Univerzitet u Beogradu, Medicinski fakultet
}

\begin{abstract}
Dijabetes mellitus (DM) i maternalna gojaznost su povezane sa neželjenim perinatalnim ishodima. Procena uticaja udruženosti ovih entiteta na ishod trudnoće je od velikog značaja.

Cilj studije je bilo određivanje povezanosti DM i maternalne gojaznosti sa neželjenim ishodima porođaja.

Evaluirani su trajanje i način završavanja porođaja, Apgar skor u prvom i petom minute, akušerske intervencije i maternalne porođajne povrede.

Žene sa DM-om su češće imale Carski rez $(\mathrm{p}<0.01)$, a ređe epiziotomiju i rascep međice $\mathrm{u}$ odnosu na trudnice bez DM-a (all $\mathrm{p}<0.05)$. Povezanost DM-a i gojaznosti sa drugim neželjenim ishodima porođaja nisu nađene.
\end{abstract}

Keywords: dijabetes mellitus, gojaznost, ishod porođaja

\title{
Introduction
}

The prevalence of diabetes, overweight and obesity have considerably amplified in the last decades. Diabetes mellitus (DM) and maternal obesity are in parallel related with adverse maternal and neonatal outcomes ${ }^{1}$, ${ }^{2}$. Both share familiar metabolic characteristics such as increased insulin resistance, hyperglycemia, and hyperinsulinemia, and DM may impart distinct effects on clinical outcomes independent of obesity alone. The same is true for maternal obesity, even though dissimilarities in metabolism may also be present among certain ethnic groups ${ }^{3}$. For that reason, examination of the combined association of these common metabolic problems with pregnancy outcomes is an important question.

Fetal distress, meconium staining, arrest disorders, hemorrhage, complex peridural access and operatory time are also increased in obese women and pregnant women with DM. Furthermore, evidence of increased risk for cesarean section, endometritis, prolonged hospital stay, thromboembolic phenomena, anemia, urinary tract infection, prematurity and fetal demise have been described ${ }^{4}$.

Objective of our study was to determine associations of diabetes mellitus and obesity with adverse delivery outcomes. 


\section{Materials and Methods}

In our retrospective cohort study, the clinical database of births in University Clinic for Gynecology and Obstetrics "Narodni front", Belgrade, Serbia from April the 1st 2013 to $30^{\text {th }}$ of June 2013 was used. University Clinic for Gynecology and Obstetrics "Narodni front" is a tertiary referral hospital in Belgrade, Serbia with a different ethnic populace and roughly 7000 deliveries per annum. The database of births consists of deidentified collected maternity data for all births in the clinic, which includes demographic data, antenatal complications, and detailed delivery and newborn data. Maternal body mass index (BMI) was calculated using maternal height and weight measured to the nearest centimeter and kilogram, and obesity was defined as BMI $>30 \mathrm{~kg} / \mathrm{m}^{2}$. The primary outcome measures were duration of labor, mode of delivery, Apgar scores in 1 st and 5th minute, obstetric interventions and maternal injuries at births.

\section{Results}

The prevalence of DM in our study population was $9.95 \%$. Table 1 . shows the characteristics of study population and observed outcomes in subgroups of DM and Non DM mothers. The prevalence of obesity within DM women was $6.45 \%$.

\begin{tabular}{|l|c|c|c|}
\hline & Non DM & DM & p \\
\hline N (\% within all deliveries) & $1403(90.05)$ & $155(9.95)$ & \\
\hline $\begin{array}{l}\text { Characteristics of study population } \\
\text { and observed outcomes }\end{array}$ & N (\% within subgroup) & N (\% within subgroup) & \\
\hline Age* & $33.2 \pm 5.0$ & $34.7 \pm 4.89$ & $>0.05$ \\
\hline Primigravida & $756(53.88 \%)$ & $79(50.97 \%)$ & $>0.05$ \\
\hline Secundigravida & $488(34.78 \%)$ & $54(34.84 \%)$ & $>0.05$ \\
\hline Tercigravida & $127(9.05 \%)$ & $14(9.03 \%)$ & $>0.05$ \\
\hline Multiparity & $37(2.64 \%)$ & $3(1.93 \%)$ & $>0.05$ \\
\hline Twins & $46(3.28 \%)$ & $5(3.23 \%)$ & $>0.05$ \\
\hline Triplets & $4(0.28 \%)$ & $0(0 \%)$ & $>0.05$ \\
\hline Breech presentation & $9(0.64 \%)$ & $1(0.64 \%)$ & $>0.05$ \\
\hline Gestational week at delivery* & $38.1 \pm 2.32$ & $39.1 \pm 2.31$ & $>0.05$ \\
\hline Labor duration in minutes* & $253 \pm 199$ & $249 \pm 262$ & $>0.05$ \\
\hline Episiotomy & $675(48.11 \%)$ & $63(40.64 \%)$ & $<0.05$ \\
\hline Repair of vaginal mucosa & $83(5.92 \%)$ & $2(1.29 \%)$ & $<0.05$ \\
\hline Perineal repair & $131(9.34 \%)$ & $14(9.03 \%)$ & $>0.05$ \\
\hline Ventouse-assisted birth & $26(1.85 \%)$ & $4(2.58 \%)$ & $>0.05$ \\
\hline Forceps & $0(0 \%)$ & $0(0 \%)$ & NA \\
\hline Cesarean Section & $403(28.72 \%)$ & $58(37.45 \%)$ & $<0.01$ \\
\hline
\end{tabular}

Table 1. Characteristics of study population and observed outcomes in subgroups of DM and Non DM mothers

*- is presented as mean $\pm \mathrm{SD}$; NA - not applicable; $\mathrm{N}$ - Total number; 
Characteristics of study population and observed outcomes in subgroups of DM Obese and DM Non Obese mothers are presented in Table 2.

\begin{tabular}{|l|c|c|c|}
\hline Group & Obese DM $(\mathrm{X} \pm \mathrm{SD})$ & Non Obese DM $(\mathrm{X} \pm \mathrm{SD})$ & $\mathrm{p}$ \\
\hline Age (year) & $34,2 \pm 5,1$ & $33,7 \pm 4,9$ & $>0.5$ \\
\hline Gestation age & $38,5 \pm 2,2$ & $39,0 \pm 1,9$ & $>0.5$ \\
\hline Labor duration (minutes) & $241 \pm 268$ & $214 \pm 178$ & $>0.5$ \\
\hline Birth weight (in grams) & $3545 \pm 435$ & $3400 \pm 561$ & $>0.5$ \\
\hline Birth length (in cm) & $51,6 \pm 1,5$ & $51,2 \pm 2,89$ & $>0.5$ \\
\hline Apgar score (1 ${ }^{\text {st }}$ minute) & $8,8 \pm 0,79$ & $8,9 \pm 1,25$ & $>0.5$ \\
\hline Apgar score (5 $5^{\text {th }}$ minute) & $9,5 \pm 0,91$ & $9,6 \pm 1,14$ & $>0.5$ \\
\hline
\end{tabular}

Table 2. Characteristics of study population and observed outcomes in subgroups of DM Obese and DM Non Obese mothers

\section{Conclusions}

The association of Cesarean Section and DM seems to be a fact $1,2,4$. Without going into the causes for this association, our observation that women with DM were more likely to have Cesarean Section, confirms this coherence. In relation to observed variables, women who had DM were less likely to have had an episiotomy and perineal repair than women without DM (all $\mathrm{p}<0.005)$. This might be explained with the higher Cesarean Section rates in population of women with DM, bearing in mind that caesarean section excludes the creation of these injuries. Obesity and greater weight gain independently increase the risk of cesarean delivery, prolonged duration of labor, as well as of several adverse outcomes with vaginal delivery ${ }^{4,5}$, although our study could not confirm this statement. This is probably due to the fact that our study involved insufficient number of obese women with DM. Large prospected studies are needed for further evaluation of risks of adverse outcomes of delivery related with DM and obesity.

\section{Literature}

1. Owens LA, O’Sullivan EP, Kirwan B, Avalos G, Gaffney G, Dunne F. ATLANTIC DIP Collaborators. ATLANTIC DIP: the impact of obesity on pregnancy outcome in glucose-tolerant women. Diabetes Care 2010; 33:577-579.

2. Landon MB, Mele L, Spong CY, et al.; Eunice Kennedy Shriver National Institute of Child Health, and Human Development (NICHD) Maternal-Fetal Medicine Units (MFMU) Network. The relationship between maternal glycemia and perinatal outcome. Obstet Gynecol 2011; 117: 218-224.

3. World Health Organization. Definition, diagnosis and classification of diabetes mellitus and its complications: Report of a WHO Consultation. Part 1: Diagnosis and classification of diabetes mellitus. Geneva, Switzerland, World Health Organization, 1999.

4. Seligman LC, Duncan BB, Branchtein L, Gaio DS, Mengue SS, Schmidt MI. Obesity and gestational weight gain: cesarean delivery and labor complications. Rev Saúde Pública 2006; 40(3):457-65.

5. Iyoke CA, Ugwu GO, Ezugwu FO, Lawani OL, Onyebuchi AK. Retrospective cohort study of the effects of obesity in early pregnancy on maternal weight gain and obstetric outcomes in an obstetric population in Africa. Int J Womens Health. 2013; 14 (5): 501-7.

Author for correspondence: dr Jovana Radakovic E-mail: radakovic.jovana@gmail.com Address: Radojke Lakic 6, Beograd, Srbija 